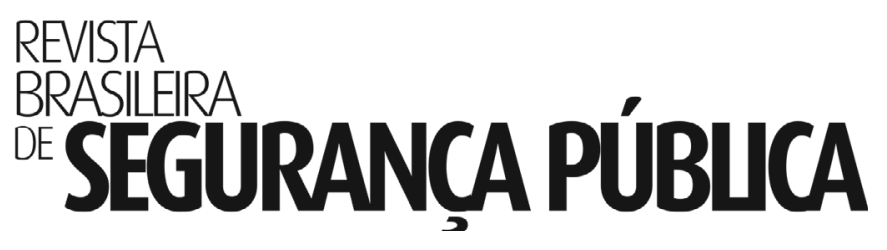

\author{
Volume 12 \\ Número 2 \\ Agosto/Setembro de 2018
}

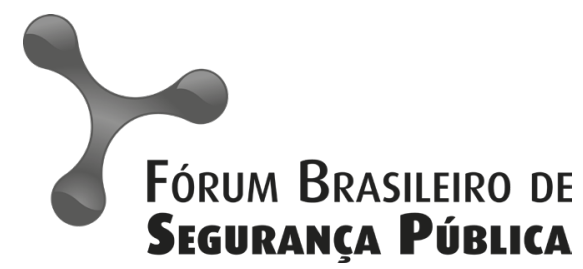

ISSN 1981-1659 


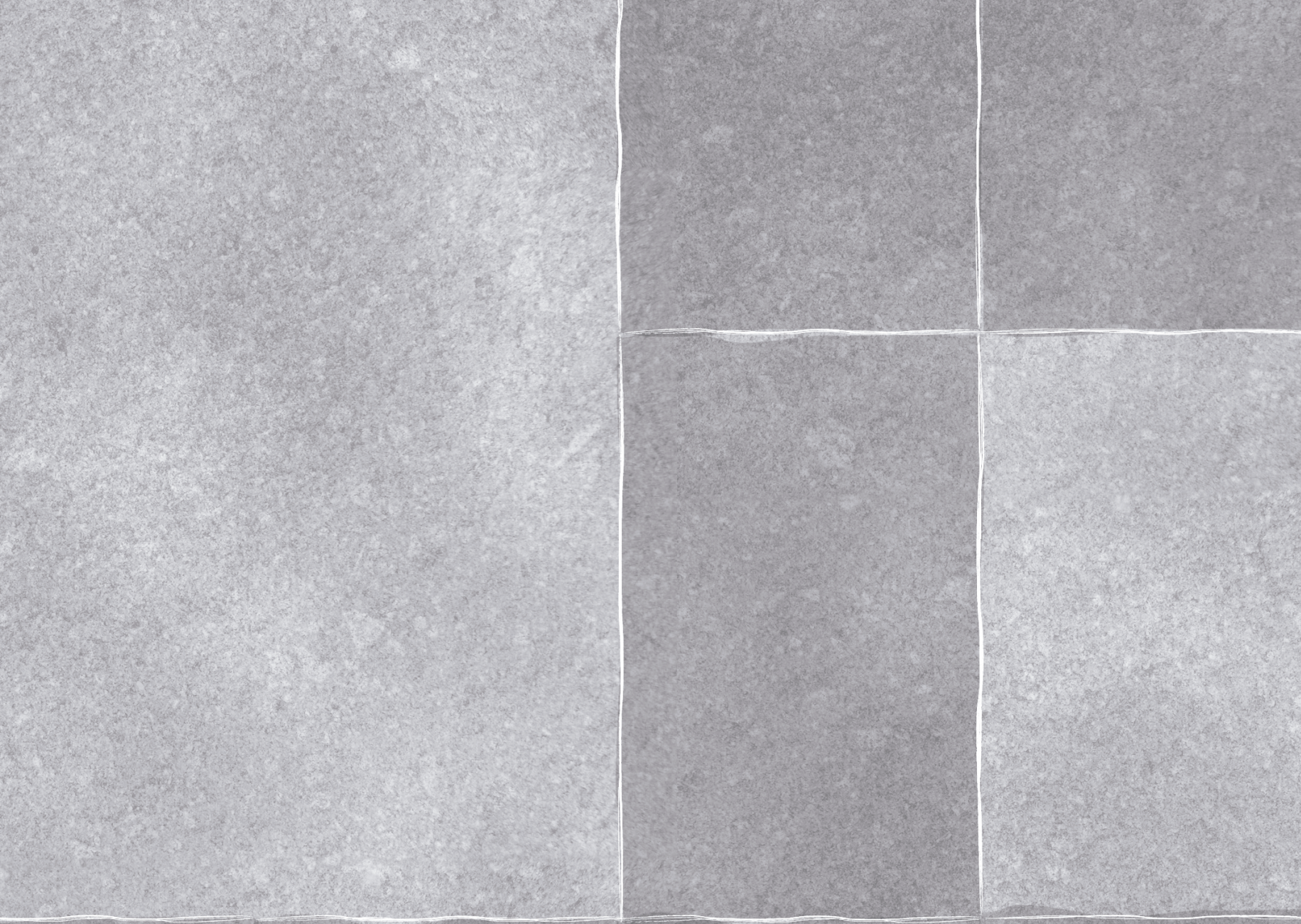




\title{
A Violência no Campo: representações sociais de futuros professores campe- sinos
}

\section{Luiz Paulo Ribeiro}

Psicólogo, Doutor em Educação: Conhecimento e Inclusão Social (UFMG), realizou residêncio de pós-doutoramento com pesquiso sobre identidade e representações sociais. É professor adjunto no Departamento de ciências Aplicadas à Educação do Faculdade de Educação da Universidade Federal de Minas Gerais.

\section{Maria Isabel Antunes-Rocha}

Psicóloga, Doutora em Educação (UFMG), realizou pós-doutoramento na UNESP. É professora associada no Departamento de Ciêncios Aplicadas à Educação da Faculdade de Educação da Universidade Federal de Minas Gerais.

\begin{abstract}
Data de recebimento: $18 / 06 / 2018$
Data de aprovação: 19/12/2018

DOI: 10.31060/rbsp.2018.v12.n2.950
\end{abstract}

\begin{abstract}
Resumo
o presente trabalho analisa as representações sociais sobre a violência de educandos do curso de Licenciatura em Educação do Campo de uma instituição pública do estado de Minas Gerais. Para tanto, foram realizadas 17 entrevistas com alunos dessa formação que apresentam vinculação com o campo. Uma análise de conteúdo conjugada com análise léxica por meio do software IRaMuTeQ ® revelou cinco classes de conteúdo representacional, cado uma delas ligada o um aspecto descritivo ou interventivo sobre a violêncio no campo. A representação social sobre a violência para o grupo de educandos se organiza em torno do descrição/vivência e do intervenção/oção coletiva que reproduz as tensões entre ogronegócio e agricultura e entre os movimentos sociais do campo e latifundiórios. Foi possível verificar que se trato de uma representação social complexa, jó que envolve outras representações, que, ao ancorar em discursos de resistêncio ou assistencialismo, podem representor um avanço ou retrocesso no que diz respeito ao acesso às políticas públicas.
\end{abstract}

\section{Palavras -Chave}

Violêncio; Representações sociais; Educoçõo do Compo; IRoMuTeQ. 


\section{Abstract \\ Social representations on violence of peasant teachers in training}

The present work analyzed the social representations about the violence of students of the course of teacher training for rural schools in a university in Brazil. Seventeen interviews were conducted with students of this training who are related to the field. Dato analysis was done with content analysis conjugated with lexical analysis through the software IRoMu$T e Q \otimes$ and revealed five classes of representational content, each linked to a descriptive or interventional aspect about violence in the field. The social representation on violence for the group of students is organized around the description / experience and the intervention / collective action that reproduces the tensions between agribusiness and agriculture and between the social movements of the countryside and landowners. It was possible to verify that this is a complex social representation, since it involves other representations, which, by anchoring in resistance or assistentialism discourses, con represent a step forward or backward in terms of access to public policies.

\section{Keywords}

Violence; Social representations; Rural education; IRaMuTeQ. 


\section{INTRODUÇÃO}

A violência é um fenômeno presente nas mais distintas sociedades e épocas,e estudá-la junto às populaçóes campesinas brasileiras é, de alguma forma, atender às lacunas apontadas por Martín-Baró (2011) no que diz respeito à necessidade de se fazer psicologia na América Latina. Por assim ser, (re)conhecer a violência no campo é rever a história e verificar que os povos campesinos brasileiros lutam pela sobrevivência, enfrentando investidas governamentais, tensóes com os modelos de produção capitalista e a exploração/expropriação de seus direitos.

Por assim ser, historicamente a violência engendrou açóes em busca dessa sobrevivência pelas populaçóes do campo: migrar para os centros urbanos, atuar como salteadores de estradas compondo grupos de bandoleiros, organizar comunidades para viverem de forma comunal (como em Canudos, Contestado e experiências quilombolas), colocar-se a serviço de um grande proprietário em troca de proteção e a açáo coletiva por meio de movimentos sindicais e sociais são formas que a populaçáo campesina adotou ao longo do tempo para resistir à violência (STEDILE, 2011; STARLIN; BRAGA, 2013; TOLENTINO, 2013a, 2013b; RIBEIRO, 2017).
Se, por um lado, a vinculação com a natureza (água, terra, floresta, etc.) confere materialidade a um modo de vida que é plural, por outro lado, a convivência com a violência nos diversos espaços rurais do Brasil não foi encarada com passividade (MARTINS, 1989) e engendra até os dias atuais representaçóes sociais marcadas por rastros da violência e pelas memórias socioafetivas dos povos do campo.

Cogitamos que as formas de pensar, sentir e agir destes povos em relação à violência estejam ancoradas em outras representações, como a de sujeito campesino, de campo, de escola e de campesinato. E nas disparidades entre as representaçóes encontradas, a unidade se faz presente através da luta dos povos do campo, que é "além da terra” (MENEZES NETO, 2003), isto é, as formas de se ver, se sentir e como agir estão relacionadas com uma luta que faz frente a violências históricas e que compreende a garantia de direitos: à educação, à saúde, ao lazer, à cultura, a um modo de trabalhar e se relacionar que seja compatível com as possibilidades de produção e reprodução do modo de vida camponesa (STARLING; BRAGA, 2013).

A educação assume, por sua vez, um lugar de centralidade, já que se entende que, 
para a construção de uma (nova) sociedade, é necessário romper com um modo de pensamento que inferioriza, aprisiona e secundariza as demandas do campo, ou seja, a luta pela educaçáo é uma luta pela superação das situaçóes de violência a que os povos do campo estáo historicamente submetidos. A criaçáo do Movimento Pela Educação do Campo envolve, além da luta pela criação de escolas e de oferta da Educação Básica e da Superior, o questionamento em torno da elaboração de projetos pedagógicos que atendam às demandas em torno das questóes relativas a uma formação vinculada ao projeto de vida que os camponeses estão construindo (ANTUNES-ROCHA, 2010; MOLINA, 2015; FERNANDES, 2012). Sendo assim, um dos pontos centrais a serem discutidos pela escola diz respeito às condiçóes concretas de produção da vida das populaçóes camponesas. E, por isso, a situação de violência experimentada ao longo do tempo por sucessivas gerações e as formas de resistência construídas pelas populaçóes camponesas constituem-se em um tema obrigatório no currículo escolar.

Esta pesquisa insere-se nesta discussão ao propor a investigação das representaçóes sociais da violência que os futuros educadores das escolas do campo estáo elaborando. Esses educadores são jovens e adultos que se vinculam à vida camponesa e são alunos em um curso de Licenciatura em Educação do Campo (LECampo). Estão, portanto, inseridos no movimento que busca ampliar e fortalecer a luta dos povos camponeses pelo direito à existência diante das violências sofridas. Sendo assim, estáo pressionados a elaborar uma representação social de violência que possibilite lidar com ela numa perspectiva histórica, permitindo-lhes que possam enfrentá-la como sujeitos de direitos no cotidiano e também a constituir como conteúdo curricular na escola.

A escolha pelos educandos do Curso de Licenciatura em Educaçáo do Campo se deu a partir da compreensáo de que esse contexto é por excelência um espaço/tempo no qual se materializa a busca da construção conceitual, teórica e metodológica da luta dos povos do campo em busca da organizaçáo de uma subjetividade capaz de superar o passado, enfrentar o presente e construir o futuro. Por aqui se fez necessário o diálogo com o paradigma da Educaçáo do Campo, referencial teórico que esclarece as lutas por educação dos povos do campo (ANTUNES-ROCHA, 2010; FERNANDES, 2012; MOLINA, 2015).

O referencial da Teoria das Representaçóes Sociais também apoia este trabalho, já que esta teoria/metodologia tem se apresentado na contemporaneidade como um campo de estudo profícuo devido às mudanças frequentes na sociedade. Diante disso, resgata-se que a Teoria das Representaçóes Sociais (TRS) têm sua origem na Psicologia Social e na Psicossociologia e que expressam "[...] conjuntos dinâmicos, [...] a produçáo de comportamentos e de relaçáo com o ambiente, da ação que modifica uns e outros [...]" (MOSCOVICI, 2012, p. 47), ou seja, envolvem a busca do entendimento sobre a dinâmica individual e social a qual mobiliza os sujeitos para sentir, pensar e agir. A representaçáo social é algo vivo, que está imbricado com a intençáo do sujeito para com a sociedade (e vice-versa) e a interação entre eles, numa relação intensa, de ir e vir, na qual tanto o sujeito quanto a sociedade produzem e re- 
produzem conceitos, símbolos e imagens (MOSCOVICI, 2003).

Por assim serem, as Representaçóes Sociais (RS) implicam na estruturaçáo e processualidade da relaçáo entre o sujeito e o objeto, proporcionando uma simbolização e interpretação, substituindo-o e conferindo-lhe significaçóes. Esses fenômenos estáo no limiar das relaçóes entre os indivíduos e a sociedade, produzidas pelo triângulo sujet-alter-objet, uma proposta de Serge Moscovici (JODELET, 2009). Ademais, os elementos de uma RS não são isolados: ela é composta por crenças, opiniôes, informaçóes e pensamentos interligados e interdependentes (MOLINER, 2001). Dessa forma, as RS exercem três funçōes essenciais: "[(a)] são formas coletivas de interpretação e compreensão do desenvolvimento social, [... (b)] exercem a regulação das relações intergrupais, contribuindo para as identidades sociais [e, (c)] permitem a evoluçáo do desenvolvimento social e justificam as condutas" (MOLINER, 2001, p. 34).

As representações sociais são relacionadas de forma indissociável às práticas sociais, ambas mobilizando-se de forma mútua. Essas representaçóes guiam e determinam as práticas sociais, e estas agem na criação ou na transformação daquelas, num movimento espiral e contínuo, com diversas idas e vindas (TAFANI e BELLON, 2005), no qual o movimento dos indivíduos dentro do campo social se traduz em evoluçôes no nível das RS (MOLINER, 2001).

Assim, este artigo tem como objetivo analisar as representaçóes sociais dos futuros educadores das escolas do campo sobre a violência e, por assim buscar, vincula-se a um grupo de estudos que relaciona a Educaçáo do Campo com a Teoria das Representaçôes Sociais, ou seja, relaciona a psicologia social com as demandas dos povos do campo (ANTUNES-ROCHA, 2012; DIAS; DIAS e CHAMON, 2016).

\section{No Rastro da Violência: conceito e ações dos campesinos no Brasil}

Considerar a violência como inerente à vida humana faz com que se pense na existência de um homo violens para designar essa proximidade do homem e a violência, já que "a lista de violências individuais ou coletivas pelas quais os homens permanecem culpáveis é interminável" (DADOUN, 1998, p. 9),além de que a própria etimologia latina permite essa aproximação, já que violência vem de vis, que significa violência, assim como força, vigor, potência, designando o emprego da força e, de forma surpreendente, também servindo para marcar o caráter essencial, a essência do ser. Mas essa definiçáo etimológica estaria certa? Essa natureza autodestrutiva seria a única via para o entendimento do fenômeno? O homem está fadado a viver uma vida de violência para sempre?

O que se pode ver é que o desprezo pela vida alheia, pela natureza e pelos animais tem sido justificado pelas boas intençóes de batalha - atacar para se sentir protegido, revidar para se proteger, destruir para poder (r)existir. Existe o emparelhamento dos ideais de justiça com os ideais de bondade: fazer justiça a um povo em detrimento do outro significa poder atacá-lo sem piedade, a fim de pacificar o mundo, pois "O justo é bom e o injusto é mau" (SOREL, 1992, p. 36). Assim, os atos vio- 
lentos adquirem legitimidade, sendo autorizados desde que para o bem comum, pelo bem da propriedade, pela salvaçáo e pela paz mundial. Mas a que preço? Até que ponto essa violência deve ser aceita? $\mathrm{O}$ que os homens estáo dispostos a sacrificar para vivenciar um mundo de paz e tranquilidade? Quais as consequências dessas práticas? Até quando o ser humano se vangloriará pelo heroísmo da criminalidade da violência? Qual o papel da violência nas relaçóes sociais atuais? Que subjetividades têm sido produzidas a partir dessa violência cotidiana?

Nota-se que a convergência para um único significado de violência torna-se quase uma tarefa impossível, já que o termo se perde na pluralidade do seu sentido e as diferentes formas de manifestação dificultam uma definição consensual, devido a posicionamentos divergentes em relaçáo ao papel da violência na constituiçáo da sociedade (FLORES, 2002; BIRMAN, 2009; VANDENBOS, 2010; VAN NIEKERK e BOONZAIER, 2015).

Porém, no âmbito agrário, o significado e as causas da violência podem ser entendidas como "o uso da força como uma reaçáo arbitrária e ilegítima contra outra pessoa ou grupo social, resultado do enfraquecimento das relaçóes políticas de poder" (SAUER, 2008, p. 243). O pedido a ser feito é que se suprima a concepção de uma violência como algo irracional (ARENDT, 2009) ou como uma irrupção do primitivo (MARTUCCELLI, 1999). Ao contrário, indica-se uma violência racional, material e fatídica. Racional, dada a consideração arendtiana de que toda violência tem uma justificativa, uma permissão - a descoberta de uma justificativa para a violência a relega à legitimidade, à normalidade. A materialidade dessa violência se dá pela sua real repercussão na vida dos sujeitos envolvidos, por irromper no cotidiano uma alteração nas formas de pensar, sentir e agir, fazendo com que os sujeitos a experimentem diretamente em suas vidas. Assim, nesses entremeios, a violência também é um fato, fato fundante, com uma história e com um marco social.

Ademais, na relação entre violência e poder, considera-se que a violência destrói o poder, mina as forças sociais (ARENDT, 2009). Essa visão da violência corrobora o entendimento da violência aplicada aos movimentos sociais atuais e históricos. Seja nas suas formas físicas, institucionais ou simbólicas, as violências contra os povos do campo por vezes se identificaram com um posicionamento necessário para se retomar o poder que parecia estar perdido.

Nesse âmbito, também se pergunta qual o papel da violência atual em relação à revolução social futura, partindo dos resultados imediatos que já temos em afinidade das suas consequências no futuro: elas facilitam a diminuiçáo dos conflitos? Elas enfraquecem a classe dominante, ou elas a fazem tomar força? Qual o resultado da inserçáo da violência entre as classes dominantes e dominadas? "A violência desaparecerá quando a educaçáo popular for mais avançada"? (SOREL, 1992, p. 65).

Diante dessas reflexóes sobre a violência, conseguiu-se concretizar o que se considera como sendo a violência: é ao mesmo tempo experiência, fato, fenômeno e momento histórico que acontecem, rompendo o fluxo esperado para a vida 
humana e social. Ela é mutualmente efeito da sensaçáo da perda de poder e resultado da hegemonia de determinada classe, é instrumento de dominaçáo e de sofrimento, é resultado da ausência de acesso a direitos. A violência acontece nas mais íntimas relaçôes assim como nos maiores envolvimentos políticos, havendo gradaçóes daquela à esta. Inicialmente atrelada a uma força motriz - e aí necessária — da evolução histórico-social, entende-se que, na verdade, não há como vivenciar a violência sem a produção de algo — ela não é necessária, mas, quando se faz presente, movimenta os sujeitos.

Nesse sentido, partindo do que foi postulado por Ribeiro (2017), tomando por base os estudos de Stedile (2011), Starling e Braga (2013) e Tolentino (2013a, 2013b) que abordam a história brasileira, em síntese ${ }^{1}$, o que se viu em relação às investidas desenvolvimentistas e suas relaçôes com a violência no campo é que elas possibilitaram alguns tipos de movimentos dos sujeitos campesinos que se cogita estarem relacionados às representaçóes sociais (RS) — formas de pensar, sentir e agir — da violência, aliando experiência subjetiva com memória social e identidade (MOLINER; DESCHAMPS, 2014).

Segundo Stedile (2011), os portugueses aportaram em território brasileiro e impuseram suas leis e normas, implementando um modelo inicialmente extrativista e depois agroexportador de estilo plantation. O genocídio histórico de índios nessa época foi retratado como forma de dominar o espaço descoberto e disciplinar as populaçôes originárias, tendo em vista que nem todos se submeteram às ordens e ao trabalho impostos pelos descobridores.

Muitos escravos, já trazidos ao Brasil-colônia sob forte repressão e violência, ao chegarem aqui foram submetidos às precárias condições de sobrevivência e de trabalho encontrados. Contudo, a insatisfação com tais questóes fazia com que os escravos se revoltassem e fugissem. Nesse período, muitos foram os escravos que, ao serem recapturados, foram mortos ou submetidos a longas torturas. Muitos desses sujeitos, para não se submeterem ao regime, tentavam fugir para os quilombos.

Outros sujeitos campesinos começaram um enfrentamento com as mesmas proporçóes dos seus agressores, formando os grupos armados, como os cangaceiros. Sobre estes, dizemos que houve uma RS que os mobilizou a agir da mesma forma que seus agressores. Assim, "Olho por olho e dente por dente" aparece como uma máxima de um posicionamento de que para viver no campo é necessário armar-se e lutar com agressividade.

Ainda há aqueles que estagnaram suas vidas em uma situação de miséria e pedantismo, numa vida paupérrima, sem condiçóes de se desenvolverem e sendo vítimas eternas como "coitados da terra" alvos de constantes promessas de governo, por vezes se submetendo às condições precárias impostas pelos agressores e aceitando os desígnios de seu destino. Esses sujeitos

1 A intenção neste momento não é remontar a história, mas apontar, nos diversos momentos vivenciados pelos sujeitos do campo, como estes reagiram à violência e as possíveis representações sociais vinculadas a esses momentos. Para a reconstrução aprofundada da história desses momentos, sugerimos as obras destedile (2011); Starling e Braga, (2013); Tolentino (2013a, 2013b) e Ribeiro (2013). 
também representam o campo como um lugar negativo e sem desenvolvimento, mas, por impossibilidade de agir contra os agressores, não se movimentam, aceitando sua condição de submissos.

Outros sujeitos, por sua vez, partiram em busca de um éden campesino, um espaço de convívio, de religiosidade e de esperança, resultando nos movimentos quilombolas e messiânicos, que, apesar de sua proposta para avida em comunidade, foram tidos como insurgentes contra a moral e os costumes do país e foram todos exterminados. Nestes, notou-se uma RS em que, para continuar a viver no campo, era necessário fugir e fundar uma sociedade alternativa à realidade.

Ao serem violentados, muitos campesinos desistiram da vida no campo e partiram numa migraçáo para as cidades e grandes centros urbanos, o que resultou em índices significativos de êxodo rural e na consideração de que o campo é um lugar de não crescimento. Essa ideia vigora até os dias atuais e potencializa a discriminaçáo e a dicotomia entre o urbano e o rural, estando relacionada a uma RS de um campo sem possibilidades e uma cidade portadora do progresso.

Por fim, existem aqueles que se organizaram em movimentos, sindicatos, associaçóes e coletividades em luta por seus direitos, pela possibilidade de plantar e viver junto da terra, por condições de desenvolvimento e de (re)produção da vida de formas justas e igualitárias. É desta vertente que surge a luta pela Educaçáo do Campo, considerada aqui como uma das formas de superar as violências que acometem os povos do campo. Cogitou-se que desses sujeitos surge uma representação social segundo a qual é necessário enfrentar a violência com outras armas, como a Educação e o Protagonismo Social. Para eles, o campo é um lugar de desenvolvimento e de produçáo de vida digna e de qualidade.

Falar da Educação do Campo é necessariamente abordar a tensáo entre o agronegócio e o campesinato e entender que os paradigmas econômicos, sociais e teóricos, modelos de desenvolvimento, são tributários da polarização desta tensão (MOLINA, 2015). O campo do agronegócio é diferente do campo da agricultura familiar e da Educação do Campo. Eles se expressam e têm consequências diferentes nos seus territórios. Se, no primeiro, o produtivismo e o desenvolvimento a qualquer custo são privilegiados e tratados como fonte de lucro, no segundo o território é lugar de vida e de desenvolvimento sustentável (geraçáo de emprego, sociabilidade e protagonismo). "Agro-Negócio" e "Agri-Cultura" diferenciam-se nas formas de ver, pensar e agir no/do campo (MOLINA e FERNANDES, 2005). A nosso ver, as formas de ver e praticar, justificar e aceitar a violência contra as populaçóes do campo também são signatárias da polarização.

O que se pode inferir, mesmo de forma superficial, é que, a cada período de desenvolvimento rural no Brasil, houve açóes de violência contra as populaçóes do campo e diante dessas representaçóes sociais engendradas por esses elementos. $\mathrm{O}$ que se pode verificar também é que, apesar de uma perspectiva histórica e da superação de modelos econômicos, os povos do campo continuam sendo vítimas da violência física, simbólica e estrutural que faz 
com que os sujeitos campesinos produzam concomitantemente todas as RS elencadas acima: fugir, lutar (resistir pelos movimentos sociais), violentar, refugiar-se e aceitar.

\section{Percurso Metodológico}

Este estudo se enquadra no hall de estudos qualitativos da área das ciências da educação e da psicologia social, orientado pelo materialismo histórico-dialético e operacionalizado pela Teoria das Representaçōes Sociais na abordagem processual (JODELET, 2014; 2009).

A coleta de dados foi efetuada através da aplicação de 108 questionários e 17 entrevistas semiestruturadas aos alunos do curso de Licenciatura em Educação do Campo de uma Instituiçáo Federal de Educação Superior durante o verão de $2016^{2}$. Os sujeitos foram selecionados a partir dos questionários, nos quais foi observada a disponibilidade desses indivíduos para participar da pesquisa, assim como o relato de experiência anterior para com a violência.

Os dados foram transcritos e tratados através da análise de conteúdo por categorias conjugada com a análise léxica com auxílio do software IRaMuTeQ (CAMARGO e JUSTO, 2013). A saber, este software é livre, tem origem francesa e é utilizado nas pesquisas sobre representaçóes sociais por ser similar ao Alceste. Seu método consiste na identificação de categorias e relações entre estas, mapeando um vocabulário típico de cada categoria, contrapondo-o a variáveis grupais e possibilitando o reconhecimento de classes na representa- ção social (CAMARGO e JUSTO, 2013; DIAS; DIAS e CHAMON, 2016).

Dos 130 (cento e trinta) alunos do curso de Licenciatura em Educação do Campo regularmente matriculados e frequentes no verão de 2015-2016, foram coletadas respostas de 108 (cento e oito) respondentes. Destes, 74 (setenta e quatro) são do sexo feminino (69\%) e 34 (trinta e quatro) são do sexo masculino (31\%). Note-se que se trata de um curso com muitos adultos jovens (63\% entre 18 e 30 anos), na sua maioria oriundos de uma escolarização recente e, por isso, essa especificidade incide nos resultados desta pesquisa, assim como demonstra mais uma preocupaçáo do curso, que é a possibilidade de que os jovens de origem campesina vejam os espaços rurais como uma possibilidade de vida e de desenvolvimento.

Os sujeitos respondentes do questionário são de origem de 29 (vinte e nove) localidades diferentes das regióes mineiras do Vale do Jequitinhonha e Mucuri, Vale do Rio Doce, Norte de Minas e Zona da Mata - municípios de baixa densidade populacional, assim como regióes consideradas pobres e com grande presença de áreas de monocultura de eucalipto e soja, e exploração de minério. Também são áreas de predominância de vegetação de cerrado e clima quente e seco. Esses municípios estão localizados nas regióes mais pobres do estado de Minas Gerais, nas quais há o maior índice de conflitos por terra.

É possível indicar também que grande parte desses municípios foi ocupada por 
plantaçóes da monocultura de eucalipto entre os anos de 1960, 1970 e 1980, que, em diversos casos, para se efetivar, expulsou famílias camponesas de suas terras (ANDRADES e GAMINI, 2007).Enfatize-se o município de Rio Pardo de Minas, do qual se originam muitos estudantes ( $41 \%$ dos respondentes), que tem sido retratado como um local de movimento em busca de melhores condiçôes para a Educação do Campo; em sequência, o município de Icaraí de Minas ( $9 \%$ dos respondentes), que tem seguido essa mesma lógica em busca do empoderamento dos sujeitos do campo.

Violência no campo: caracterizações, conteúdos e classes da representação social

O material analisado pelo IRaMuTeQ é composto de17 unidades de contexto inicial (UCI) ou entrevistas, e foi dividido em 1.480 unidades de contexto elementar (UCE), sendo retida para análise 77,91\% da totalidade do corpus, ou seja, $1.153 \mathrm{seg}$ mentos de texto foram utilizados para esta análise. O software utilizado subdividiu o corpus em cinco classes, constituindo o dendrograma presente na figura 1 .

A Classe 1 foi denominada Informaçáo e Posicionamento, constituída de223 UCEs (trechos de texto), concentrando $19,34 \%$ do corpus. Essa classe apresenta características informacionais e analíticas sobre a violência no campo, sendo composta pelos saberes e conhecimentos sobre a violência. As palavras "saber", "coisa”, "poder", "outro", "acontecer", "vez", "muito" e "pouco" foram constatadas mais frequentemente. Esse saber sobrea violência passa pela avaliaçáo do cotidiano, das vezes que ela aconteceu consigo e com o outro, do julgamento da sua quantidade, se é muito ou pouco, e da indicação que a violência é uma "coisa" (sujeito, objeto ou ação?) que está presente na experiência dos sujeitos.

Observou-se ainda que nessa classe houve prevalência de sujeitos do sexo feminino, que iniciaram sua trajetória naturalizando a violência e que a terminaram resistindo a ela. Pode-se avaliar que essas características podem indicar que o "saber" sobre a violência constituído em primeira pessoa abre caminho para o nível informacional e as possibilidades de ação diante de tal agressão. Portanto, saber se é pouco ou se está em demasia é, com os elementos informacionais, julgar e ter um posicionamento positivo ou não.

A vinda para a LECampo- Licenciatura em Educação do Campo - , para alguns dos sujeitos de pesquisa, foi uma forma de superar a violência. No âmbito exposto, desnaturalizar a violência e passar a resistir a ela é uma mudança atitudinal feita a partir dos elementos da informação, de um saber constituído sobre ela e sobre si, possibilitando novas ancoragens.

A gente acaba sabendo essas coisas a partir do momento em que você começa a estudar mais a escola do campo. A escola rural não te leva a pensar nisso, que tem que ser lida "no campo", porque no campo não tem uma escola do campo (Entrevistada M, 33 anos, sexo feminino, agricultora familiar, grifo nosso).

A identificaçáo da origem da informação também se faz presente nessa classe. $\mathrm{O}$ acesso ao "saber" está no âmbito do tipo de informação disponibilizado aos entrevista- 
dos, e na possibilidade ou não de questionar, produzir ou reproduzir padróes sociais de ruptura ou continuidade da violência no campo.

Seria uma oportunidade para essas pessoas [campesinos] estarem lá [na escola], permanecer lá e se reconhecer, saber que elas têm valor, que aquele local tem valor. $\mathrm{Na}$ minha opinião... nossa, essa informaçáo está tendo um papel essencial (Entrevistada M, 33 anos, sexo feminino, agricultora familiar).

A informação também leva à valorização do que se sabe, posto que o náo reconhecimento de um valor também pode ser considerado como uma violência sofrida. Permanecer na escola e se "reconhecer saber" é um ato afirmativo que só é possível a partir do momento que se sabe que a violência - nas suas mais variadas formas - existe e que é necessário resistir.

Nessa classe a coisificaçáo da violência também é característica. Isto significa, para além de um estereótipo de linguagem dos sujeitos de pesquisa, colocar a violência enquanto uma "coisa" e não a enquadrar como sujeito, ação ou objeto, tornando-a indefinida. Essa indefinição torna possível a comparaçáo e a unificação das tipologias da violência. Como afirma a entrevistada "A": "Eu moro num assentamento e às vezes pode acontecer alguma briga, alguma coisa assim. Já teve outros atos de alguma violência, roubos, mas coisa assim mais supérflua, que é de arame, galinha [...]".

A Classe 4, denominada Características da Violência, foi constituída de 208 UCEs (trechos de texto), concentrando 18,04\% do corpus. Essa classe possui âmbito per- ceptivo, ou seja, como é possível visualizar a violência, senti-la consigo ou com os outros. Nessa classe, as palavras "campo", "violência", "ver", "pessoa", "direito", "mulher" e "trabalho" são mais frequentes, e houve apenas uma variável associada: os sujeitos que, no seu posicionamento inicial, se submetiam à violência no campo a fim de sobreviver.

Passar a "ver" a violência é um elemento marcante dessa classe e explica a associação da variável dita, uma vez que há em alguns relatos dos entrevistados que atualmente, ao contrário do passado, conseguem perceber a violência que acontece ao redor de si e a si mesmos. O elemento perceptual "passar a ver" impele o indivíduo à ação, inquieta-o, coloca a violência cotidiana enquanto uma "questáo" — demandaa ser resolvida e enfrentada. Um exemplo disso são as afirmativas dos entrevistados "O" e "F":

Atualmente a gente vê que está aumentando [a violência] porque antes a gente não via muito, era mais descaso com a violência, só que hoje a gente vê muito falar sobre essa violência no campo". (Entrevistada O, 21 anos, sexo feminino, trabalhadora de uma escola do campo),

$\mathrm{Eu}$ acredito que as pessoas vão se interessar mais em permanecer ali naquele local [no campo] sem desvalorizar - ver como um lugar que náo tem nada, não tem oportunidades, é só a roça, que é essa visáo que todo jovem tem e acaba deixando esse espaço [...] Agora eu vejo essa questáo do trabalho de forma desumana, para mim é uma violência [...] essa questão do machismo que está presente em quase todas as casas do pessoal do campo é uma violência (Entrevistado F, 22 anos, sexo feminino, agricultor familiar). 


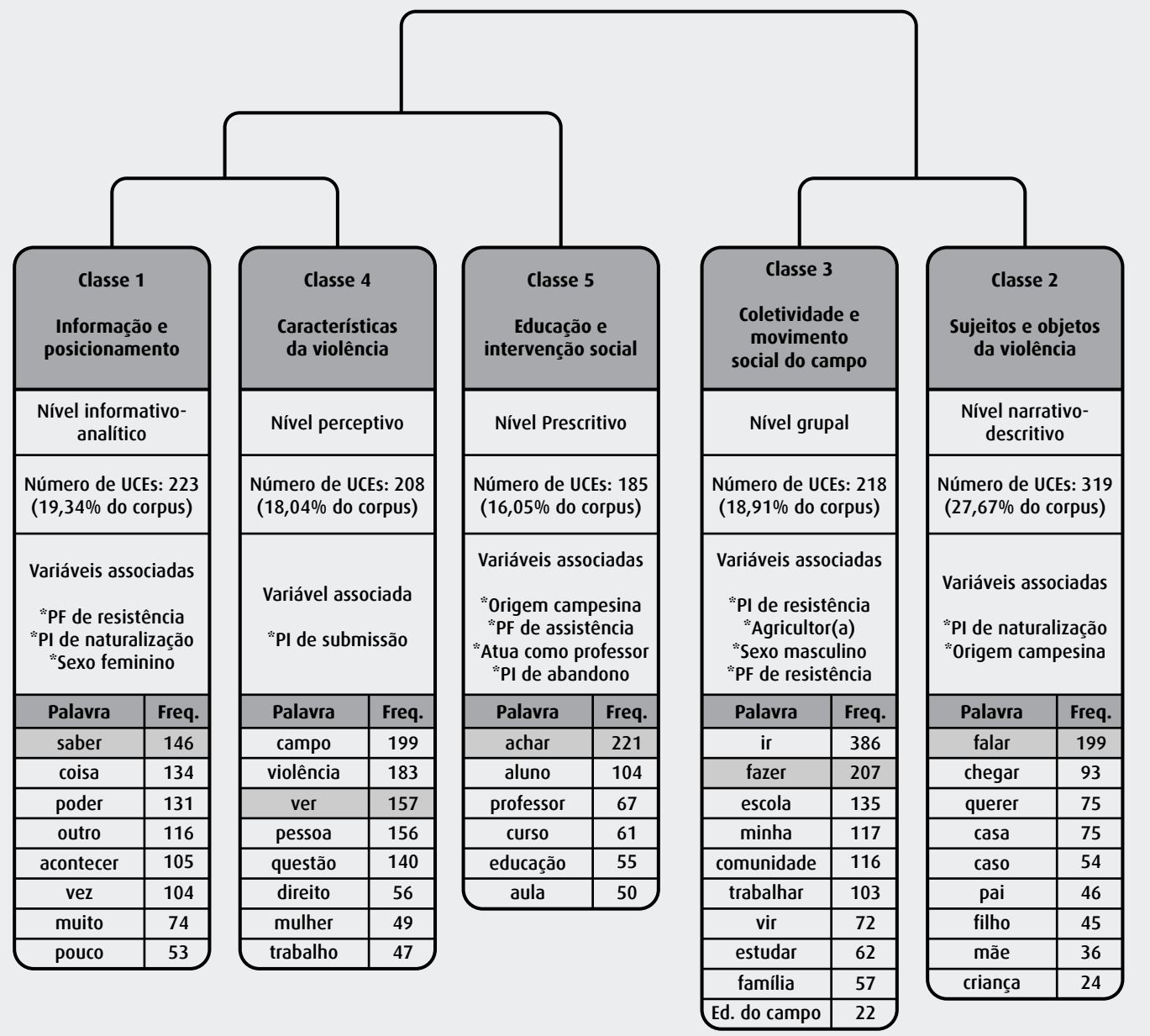

As faces do "Ver" são indício de um posicionamento, principalmente em relação às características do campo em detrimento da cidade, algo que dificulta a superaçáo de modelos de depreciação do campo e de seus sujeitos. "Passar a ver" é um movimento de perceptivelmente visualizar e conceber o campo - objetivar e ancorar - a partir de outro paradigma, de desenvolvimento e de lugar de vida.

A violência enquanto uma "questão" é colocada como interrogação, inquietação e demanda aos sujeitos e à escola do campo. Essa violência adjetivada enquanto "questão" assume, novamente, âmbitos diversos, podendo estar relacionada à sexualidade, ao trabalho ou aos papéis sociais. A palavra "questáo" é, por vezes, substituta da violência. Esta se espalha no âmbito da perda ou não garantia de direitos, seja por causa do machismo considerado cultural ou do náo conhecimento das leis trabalhistas, estando presente no cotidiano e se caracterizando de forma minuciosa como ato disruptivo. $\mathrm{O}$ direito passa a ser per- 
cebido, conhecido náo como uma arbitrariedade, mas sim como uma garantia, uma conquista social, visto que o não conhecimento é uma possibilidade de permanecer sendo violentado.

Écomo se fossem bonzinhos [sobre a empresa de silvicultura], mas não! Isso é um direito trabalhista que a gente tem e eu só percebi isso agora, tanto que eu falo para o pessoal em muitos lugares lá - muitas fazendas o pessoal não trabalha até ascinco (Entrevistada M, 33 anos, sexo feminino, agricultora familiar).

Há neste momento uma representação social de que o homem do campo é um sujeito sem o conhecimento dos seus direitos, e essa representação é mais forte entre os entrevistados que possuem origem rural, mas que moram nas cidades, e mais forte ainda naqueles que mantêm vínculo com o campo apenas enquanto professores.

Por sua vez, a Classe 5 foi denominada Educação e Intervenção Social. Apesar de ser a menos representativa enquanto tamanho de classe $(16,05 \%$ do corpus), ela foi constituída de185 unidades de texto (UCEs). Por ter caráter prescritivo, essa classe instrumentaliza a escola enquanto lócus de intervenção social na violência no campo, ou seja, ela organiza as prospecçóes sobre o papel da educaçáo diante da violência. Por assim ser, nessa classe as palavras mais expressivas foram "achar", "aluno", "professor", "curso", "educação" e "aula", sendo mais frequentes entre os entrevistados de origem camponesa, professores que iniciam sua trajetória no âmbito do abandono e/ou terminam sua trajetória com uma postura assistencialista.
Discutir as variáveis Origem Camponesa e Professores num âmbito prescritivo é, de alguma forma, marcar em qual lugar esses sujeitos têm colocado a educaçáo e qual o papel da educaçáo e sua intervenção. Uma intervenção feita na escola, com os alunos, tem duplo entendimento: primeiro, coloca a escola num patamar de instituição de promoção do desenvolvimento; e segundo, coloca a violência no campo num lócus de violência do outro, ou que acontece com o outro, colocando os professores na posiçáo de expectadores, podendo utilizar ou náo seu poder resolutivo, ao passo que os coloca em posiçáo desigual na comunidade: há que se fazer POR eles, e não COM eles — uma premissa contrária à Educação do Campo.

Ao se verificar a classe em questão, identificou-se que os sujeitos da educação sáo constituídos em um binômio professor-aluno, em que cabe ao professor a instrumentalizaçáo do aluno na melhoria da sua vida cotidiana. Persiste, então, a postura assistencialista em que a educação é o único meio de superar a violência. Nessa lógica, os elementos aluno, professor e aula podem ser lidos, respectivamente, como receptor, emissor e lugar, sendo que o professor "ajuda" o aluno.

Eu acho que é uma forma dos professores levarem para sala de aula não só dando palestra, não só em vídeos, mas a partir das disciplinas que é obrigatória (Entrevistada P, 26 anos, sexo feminino, origem campesina).

Pode... um estranho pode querer se aproximar de uma forma estranha. Ele não vai saber que tipo de carinho é esse que ele vai te dar, entáo acho 
que tem que ter essa educaçáo ensinando sobre isso para os alunos do campo (Entrevistada G, 26 anos, sexo feminino, origem campesina).

Eu já vi e já ouvi falar de muita coisa relacionada à violência no campo, em sala de aula mesmo: agressáo, arma de fogo, coisas que fazem parte do cotidiano de escola que o pessoal já acha que isso é normal (Entrevistado Q, 38 anos, sexo masculino, professor).

Eu acho que a base principal é a familia. Acho que tem que ser trabalhado nas familias, mas de que forma talvez partindo muito da questáo do essencial, da informação, trabalhar através de palestras (Entrevistada G, 26 anos, sexo feminino, origem campesina).

Aí a escola acha que já não cabe a ela mais se envolver naquele assunto [situação de violência acontecida na comunidade] e não procura nem mesmo ajudar a familia. (Entrevistada D, 21 anos, sexo masculino, professor).

Os riscos de uma intervenção social educativa baseada nessa classe estáo na desconsideração da população camponesa como sujeitos articulados capazes de superar a violência que acontece entre eles, e ainda desconsiderar o protagonismo social desses sujeitos e a extensa luta por direitos que eles já travaram ao longo de toda a história brasileira, da qual a política pública de Educação do Campo foi fruto e palco de atuação. Reduzir a educaçáo à escola é, nesse sentido, embotar os saberes prévios dos sujeitos, desmerecer a memória social deles e implantar uma educaçáo tal qual uma linha de produção, com conteúdo pronto, falsamente preocupados com a realidade da comunidade, desarticulados da vida do campo. Essa classe é marcadamente diferente das demais na análise léxica, já que está em oposição a todas as demais classes.

A Classe 3 foi chamada de Coletividade e Movimento Social do Campo e foi constituída de218 segmentos de texto, representando $18,91 \%$ do corpus. As variáveis associadas a ela estão relacionadas aos entrevistados do sexo masculino, agricultores familiares e que têm seus posicionamentos finais e iniciais em atitudes de resistência. Essa classe teve as expressōes "ir", "fazer", "escola”, "minha”, "comunidade", "trabalhar", "vir", "estudar", "família” e "Educação do Campo" como as mais frequentes e expressivas. Ela apresenta o nível grupal da representaçáo social da violência, discutindo a violência no campo a partir da participação social e da coletividade.

A flexão do verbo "ir" é a forma de relatar as experiências de luta contra a violência, luta coletiva em prol de ganhos para si e para a comunidade. É também uma forma de registro do acesso à Licenciatura em Educaçáo do Campo e, por isso, "ir" é uma forma de participar de forma coletiva de direitos adquiridos por meio da luta social. Isto é notado na fala da Entrevistada "M": "Então, de início, o que me fez gostar do curso foi a oportunidade de fazer uma graduaçáo, essa oportunidade. Eu vim porque casei muito nova, tive filho muito jovem e interrompi os estudos".

Além de as conjugações do verbo "ir" estarem presentes nessa classe, há o verbo "fazer", que representa a ação da coletividade a fim de proporcionar o enfrentamento da violência entendida como algo a ser combatido em nível comunitário. 
"Fazer" diz da participação e da preocupação de que a situação mude. Sobre isso, a entrevistada "A" diz: "Eu faço um trabatho numa escola familiar agrícola com os meninos e a maioria dos alunos é ou de pequenas cidades ou de cidades bem pequenas, praticamente rurais ou então do próprio campo".

A expressão "fazer com" e "fazer junto" são expressões da coletividade e do protagonismo dos sujeitos do campo. É uma forma diferenciada de atuaçáo, já que parte do caminho comum em busca da superação da situaçáo de violência para o todo. Diferentemente da Classe5, essa classe traz os sujeitos não como um binômio professor-aluno, mas a partir do lugar social ocupado. Apresentando as narrativas a partir desse lugar, dá-se a entender que as possibilidades de enfrentamento da violência também existam em outros espaços da vida cotidiana. Isto também é percebido na análise da Classe 2.

Por sua vez, a "escola” é um espaço de construçâo do conhecimento, identidade, pertencimento e trabalho. Uma escola fora desses parâmetros articulados com a comunidade e com o protagonismo dos sujeitos incita a busca de outras formas de educação.

Eu tenho uma identidade muito forte com ela. Não sei se é porque também participei do processo de fundaçáo da escola (Entrevistado H, 31 anos, sexo masculino, agricultor familiar).

Se não for nela [trabalhar na escola], que seja em outra do município, mas tinha vontade de ser nela. É uma escola que eu me identifico muito — filhos de agricultores que geralmente são ami- gos, né, familiares que a gente recebe nessa escola. (Entrevistada A, 36 anos, sexo feminino, agricultor familiar).

Tem jovem estudando lá [escola da cidade] e essas escolas não debatiam, mas, junto com a comunidade, era debatendo para gente perceber isso, até que a gente viu que tinha como a gente recorrer, ir atrás do estado procurar os órgáos competentes para isso. (Entrevistado I, 31 anos, sexo masculino, agricultor familiar).

Dessa forma, a comunidade e a família são vistas como células do movimento social do campo, ao passo que a comunidade é um local e, também, uma expressão do envolvimento de sujeitos em uma vida comum, lugar de fazer junto, de se articularem em busca da solução para as violências colocadas à mostra e que afetam a todos.

Por fim, a Classe 2 foi denominada de "Sujeitos e Objetos da Violência". Apresentando características narrativas e descritivas, ela é a maior das classes operacionalizadas pelo IRaMuTeQ, contando com $27,67 \%$ do corpus de análise (319 unidades de texto, UCEs). O grande número está presente em quase todas as entrevistas, porém sendo mais expressivo entre os sujeitos de origem campesina e que iniciam suas trajetórias de posicionamento naturalizando a violência. As palavras "falar", "chegar", "querer", "casa", "caso", "pai”, "filho", "mãe" e "criança" representam as mais importantes nesse âmbito e revelam a dinâmica dessa classe que, pelo seu componente narrativo, traz a descrição dos eventos considerados violentos, seja aqueles vivenciados pessoalmente, seja aqueles da memória familiar e social, ou, ainda, que fazem parte da prática profissional. 
Acho que é uma oportunidade do você poder falar assim: existe isso para o campo! Nós fomos maltratados, nossas familias foram, aí assim a gente... eu até um dia um menino falou assim: "mas eu quero me tornar um médico"; eu falei: "então você estuda!" (Entrevistado J, 43 anos, sexo masculino, agricultor familiar).

O "falar" organiza a narrativa, dá voz aos sujeitos, remete à descriçáo do fato considerado violento e, também, organiza a memória social sobre a violência. "Falar", por vezes, é a forma de o indivíduo enfrentar a violência sofrida, expor aquilo que sabe a fim de não a vivenciar novamente.

O "querer" aparece como tomada de poder para a ação e só é possível a partir dos sujeitos, tanto dos sujeitos que violentam quanto dos sujeitos que sofrem a violência. Em doses diferenciadas, "querer" é o que prende o sujeito à violência ou o liberta dela.

Nessa classe, há a presença da dialética dos indivíduos com o meio e das mudanças que esses protagonizam diante da violência. A superaçáo de um modelo dicotômico de enfrentamento da violência parte da mudança de paradigma: náo visualizar a solução da violência no binômio aluno-professor, mas sim numa construçáo social dinâmica de indignação-ação-protagonismo.

Como visto, as classes estão articuladas e refletem o que é a representação social $\mathrm{da}$ violência para os graduandos em Licenciatura em Educação do Campo. Devido à participação social dos sujeitos e ao seu envolvimento com o campesinato e na
Educação do Campo, seja no formato de agricultor familiar, origem campesina ou como professor de escolas do campo, esses sujeitos mostram-se preocupados com as situaçóes de violência que acontecem ao redor e com a escola e a comunidade campesina. Logo, as diferentes maneiras de ver o campo ditam as formas de interferir na violência e, independente da forma, o importante nesse quesito é a superação de contextos violentos e a promoçáo de uma cultura de paz, pautada na garantia de direitos dos povos do campo e da cidade, sem distinção, sem preconceito e sem sobreposição.

O que se pensa a partir da apresentação de dados é que, encontradas as discrepâncias entre as classes da representaçáo e a possibilidade de ocupação de lócus sociais diferenciados (agricultor, professor ou de camponês), há indícios de que a representação social também se modifique ao longo da trajetória da vida dos sujeitos, que, de forma individual, vão se inserindo nas tramas sociais dos lugares que vão ocupando, dos papéis sociais que vão assumindo e das formas de pensar, sentir e agir que vão sendo engendradas na vivência.

\section{Considerações finais}

A violência perpassa a subjetividade dos sujeitos participantes da pesquisa e é viva nas suas representaçóes sociais de campo, escola e campesinato. A violência no campo, vivida e representada, está na memória afetiva pessoal e na memória histórico-coletiva dos povos do campo e extrapola as definiçóes, conceituaçóes, delimitaçóes e tipificaçôes: ela existe, insiste e faz resistir.

A Educação do Campo, fruto de lutas 
dos movimentos sociais do campo, é uma das formas de resistência à violência que cinge esses povos, e, por assim ser, através dos dados se constatou o papel crucial da Licenciatura em Educaçáo do Campo nas formas de representar a violência no campo, evidenciando o quanto o curso de Licenciatura em Educaçáo do Campo contribui para a superação da violência, principalmente no que diz respeito ao acesso à Educaçáo Superior em uma instituição federal, algo que consideram difícil para muitos dos campesinos. A vivência das místicas, as discussóes e a ênfase na coletividade e na partilha de experiências facilitam o contato com realidades diferentes, inclusive de narrativas da violência em diferentes proporçóes, fazendo representar e engajando os sujeitos na resistência.

$\mathrm{Na}$ análise do IRaMuTeQ, a subdivisão em classes sobre a representação social da violência nos provoca a um entendimento de como a Educaçáo do Campo pode estar organizada: como elemento de resistência ou de assistência à violência. Enquanto elemento de resistência, ela se mostra mobilizadora de representaçóes sociais que enfatizam a necessidade de luta contra a violência historicamente institu- ída e de melhorias na educação, "gerando" sujeitos engajados nos movimentos sociais, pelas causas do campo e por uma construção educativa COM, em conjunto num bem comum, sujeitos com vivência da coletividade. Enquanto elemento de assistência, a educação se volta para o ruralismo pedagógico, destituindo o sujeito de conhecimentos da açáo sobre a violência, vitimizando-o e tornando-o incapaz de agir. Ela é uma perspectiva interventiva do PARA, em que há um sujeito superior a outro, um com poder e outro sem privilégios. Portanto, há uma polarização do modelo educativo que reproduz a tensão entre agronegócio e agricultura.

Ressalta-se que são as tensões que fazem com que os indivíduos se mobilizem em prol de mudanças. Essas tensões são denominadas de "pressão pela inferência", nas quais não há como o indivíduo se ausentar de uma produçáo subjetiva mesmo que ela seja de legitimidade de ideais, perspectivas e representaçóes sociais. Assim, um professor em sala de aula e em sua experiência pessoal depara-se com a violência, e é preciso construir algo sobre/com/ de/para ela.

\section{Referências Bibliográficas \\ ANDRADES, T. 0. ; GAMINI, R. N.Revolução verde e a apropriação capitalista. Revista CES, 2007, p.43-56.}

ANTUNES-ROCHA, M. I.. Formação de educadores e educadoras da Reforma Agrária no contexto do PRONERA: uma leitura a partir de práticas. In.SANTOS, C. A.;MOLINA, M. C.; JESUS, S. S., Memória e história do Pronera: contribuições para a educação do campo no Brasil. Braślía: Ministério do Desenvolvimento Agrário. 2010, p.121-137.
ANTUNES-ROCHA, M. I.. Da cor da terra: representações sociais de professores sobre alunos no contexto de luta pela terra. Belo Horizonte: Ed. UFMG. 2012.

ARENDT, H.. Sobre a violência. Rio de Janeiro: Civilização Brasileira. 2009.

BIRMAN, J.. Cadernos sobre o mal: agressividade, violência e crueldade. Rio de Janeiro: Record, 2009. 
CAMARGO, B.; JUSTO, A.. Tutorial para uso do software de análise textual IRaMuTeQ. Florianópolis: Laboratório de Psicologia Social da Comunicação e Cognição (LACCOS) - UFSC, 2013. Fonte: www.iramuteq.org/documentation/fichiers/tutoriel-en-portugais

DADOUN, R.. A violência: ensaio acerca do "homo violens". Rio de Janeiro: Difel, 1998.

DIAS, A. C.;DIAS, G. L.; CHAMON, E. Q. Representação social da educação do campo para professores em formação. Psicologia e Sociedade, 2,2016, p. 267-277. doi:http://dx.doi.org/10.1590/1807-03102016v28n2p267

FERNANDES, B. M.. Movimentos socioterritoriais e movimentos socioespaciais: contribuição teórica para uma leitura geográfica dos movimentos sociais. Revista NERA, 6, 2005.

FERNANDES, B. M.. Territórios da Educação do Campo. In.:ANTUNES-ROCHA, M. I.; MARTINS, M. ; MARTINS, A. Territórios educativos na Educação do Campo: escola, comunidade e movimentos sociais. Belo Horizonte: Autêntica, 2012, p.15-20.

FLORES, R. Z.. A biologia na violência. Ciência e Saúde Coletiva, 7(1), 2002, p. 197-202.disponível em http://www.scielo.br/scielo.php?script=sci_arttext\&pi$\mathrm{d}=$ S1413-81232002001000198lng=en\&nrm=iso

JODELEI, D.. O movimento de retorno ao sujeito e a abordagem das representações sociais. Sociedade e Estado, 24(3),2009, p. 679-712.

JODELET, D.. Représentation sociale: phénomènes, concept et théorie. In.: Moscovici, S.Psychologie Sociale (3éme edition ed., pp. 363-384). Paris: Presses Universitaires de France, 2014, p.363-384.

MARTÍN-BARÓ, I.. Desafios e perpectivas da Psicologia Latino-Americana. In.:GUZ7O, R.; LACERDA JR, F., Psicologia Social para a América Latina: o resgate da psicologia da libertação. Campinas/SP: Alínea, 2011, p.199219.
MARTINS, J. D.. Caminhada no chão da noite: emancipação política e libertação nos movimentos sociais do campo. São Paulo: Hucitec, 1989.

MARTUCCELLI, D.. Reflexões sobre a violência na condição moderna. Tempo Social: revista de sociologia USP, 1, pp. 157-175, 1999.

MENEZES NETO, A. J.. Além da terra: cooperativismo e trabalho na educação do MST.Rio de Janeiro: Quartet, 2003.

MOLINA, M. C.. Educação do Campo e o enfrentamento das tendências das atuais políticas públicas. Educação em Perspectiva, 6(2), pp. 378-400, 2015.

MOLINA, M. C.; FERNANDES, B. M.. O campo da educação do campo. In.: MOLINA, M. C.; JESUS, S.Por uma Educação do Campo. Brasília: Articulação Nacional "Por uma Educação do Campo", 2005.

MOLINER, P.. La dynamique des représentations sociales. Grenoble: Presses Universitaires de Grenoble, 2001.

MOLINER, P. ; DESCHAMPS, J.-C. A identidade em psicologia social: dos processos identitários às representações sociais. Petrópolis/R): Vozes, 2014.

MOSCOVICl, S.. Representações sociais: investigações em psicologia social. Petrópolis/R): Vozes, 2003.

MOSCOVICI, S.. A psicanálise, sua imagem e o seu público. Petrópolis/RJ: Vozes, 2012.

RIBEIRO, Luiz Paulo. 0 campo, a violência e a educação do campo: representações sociais sobre a violência de educandos do curso de licenciatura em Educação do Campo. Rio de Janeiro: Gramma, 2017.

STEDILE, João Pedro (Coord.). A questão agrária no Brasil: 0 debate tradicional - 1500-1960. 2ed. São Paulo: Ed. Expressão Popular, 2011.

SAUER, S. Conflitos agrários no Brasil: a construção da identidade social contra a violência. In.: BUAINAIN A. M., 
Luta pela terra, reforma agrária e gestão de conflitos no Brasil: agricultura, instituições e desenvolvimento sustentável. Campinas/SP: Editora Unicamp. 2008. P.231-265.

SOREL, G.. Reflexões sobre a violência. São Paulo: Martins Fontes, 1992.

STARLING, H. M.; BRAGA, P. Sentimentos da Terra: imaginação de reforma agrária, imaginação de república. Belo Horizonte: Editora PROEX, 2013.

TAFANI, É. ;BELLON, S. Études expérimentales de la dynamique des représentations sociales. Em J. C. Abric, Méthodes d'étude des représentations sociales. Toulouse: ERES. 2005, p. 255-277.

TOLENTINO, Thiago Lenine Tito. Margens da marcha para o oeste: luta pela terra em Trombas e Formoso, Porecatu e Sudoeste do Paraná. In.: STARLING, H.M.M.; BRAGA, O.C. (Orgs). Sentimentos da Terra: imaginação de re- forma agrária, imaginação de república. Belo Horizonte: Editora PROEX, 2013a, p. 99-115.

TOLENTINO, Thiago Lenine Tito. Repressão e Violência no Campo: do golpe civil-militar à nova república. In.: STARLING, H.M.M.; BRAGA, O.C. (Orgs). Sentimentos da Terra: imaginação de reforma agrária, imaginação de república. Belo Horizonte: Editora PROEX, 2013b, p. 159-169.

VAN NIEKERK, T.;BOONZAIER, F. A... "You're on the floor, I'm the roof and I will cover you": social representations of intimate partner violence in two Cape Town communities. Papers on Social Representations, 24, 2015, p.5.1-5.28.

VANDENBOS, G. R.. Dicionário de Psicologia da APA. Porto Alegre: Artmed. 2010. 


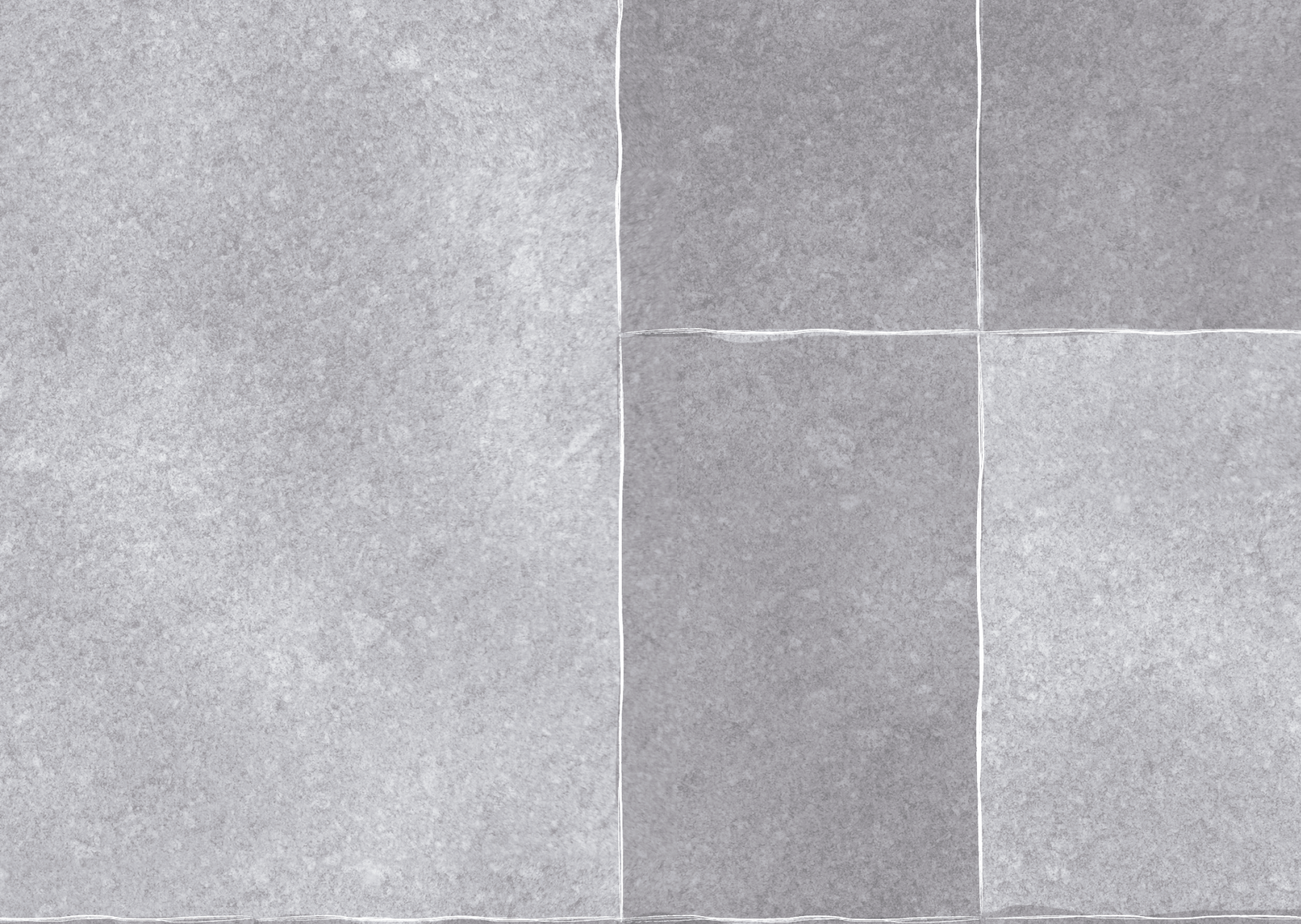

